\title{
A rare Down syndrome foetus with de novo 21q;21q rearrangements causing false negative results in non-invasive prenatal testing: a case report
}

\author{
Hui-Hui Xu ${ }^{1,2^{*}}$ (D), Mei-Zhen Dai ${ }^{1,2}$, Kai Wang ${ }^{1,3}$, Yang Zhang ${ }^{1,2}$, Fei-Yan Pan ${ }^{2}$ and Wei-Wu Shi $i^{1,2^{*}}$
}

\begin{abstract}
Background: Non-invasive prenatal testing (NIPT) has been established as a routine prenatal screening to assess the risk of common foetal aneuploidy disorder (trisomy 21, 18, and 13). NIPT has high sensitivity and high specificity, but false positive and false negative results still exist. False negative NIPT results involving Down syndrome are rare, but have a high clinical impact on families and society.

Case presentation: We described a case of a foetus that tested "negative" for trisomy 21 (Z-score was 0.664 ) by NIPT based on the semiconductor sequencing platform (SSP). The foetal fraction of cell-free DNA was 16.9\%; this percentage was much larger than the threshold of $4 \%$ for obtaining accurate NIPT results. However, postnatally, the newborn was diagnosed with Down syndrome with the 46,XY,der(21;21)(q10;q10),+ 21 karyotype.

Conclusions: We presented a case of false negative NIPT results, which may occur through biological mechanisms rather than poor quality, technical errors or negligence. It is imperative for clinical geneticists and their patients to understand that NIPT is still a screening test.
\end{abstract}

Keywords: Non-invasive prenatal testing (NIPT), False negative, Down syndrome, 21q;21q rearrangements

\section{Background}

Non-invasive prenatal testing (NIPT) based on massively parallel shotgun sequencing (MPSS) is widely available as a common clinical screening to assess the risk of foetal aneuploidy disorder (trisomy 21, 18, and 13) during pregnancy $[1,2]$. NIPT evaluates cell-free foetal DNA (cfDNA) fragments in the maternal circulation, which can be detected as early as 9 weeks of gestation, and the cfDNA fraction in the maternal plasma is approximately $5-20 \%$ between 10 and 26 weeks of gestation $[3,4]$.

\footnotetext{
*Correspondence: hui739@163.com; shiww@enzemed.com

'Prenatal Diagnosis Center, Taizhou Hospital, Wenzhou Medical University, Zhejiang, China

Full list of author information is available at the end of the article
}

A meta-analysis of 117 cohort studies based on NIPT in singleton pregnancies demonstrated sensitivity and specificity for trisomy 21 (T21, Down syndrome) of 99.4 and $99.9 \%$, for trisomy 18 (T18, Edwards syndrome) of 97.7 and 99.9\%, and for trisomy 13 (T13, Patau syndrome) of 90.6 and $100 \%$, respectively [5]. NIPT has high sensitivity and high specificity in assessing the risk of common foetal aneuploidies. However, foetal cfDNA in maternal plasma originates from apoptotic placenta cytotrophoblasts [6]. Therefore, NIPT results may not always represent the actual foetal karyotype of all foetuses; false positive and false negative results still exist [7-10]. NIPT is a screening method, and positive results should be confirmed by amniocentesis and karyotyping, which are recommended by the American College of

C C The Author(s). 2020 Open Access This article is licensed under a Creative Commons Attribution 4.0 International License, which permits use, sharing, adaptation, distribution and reproduction in any medium or format, as long as you give appropriate credit to the original author(s) and the source, provide a link to the Creative Commons licence, and indicate if changes were made. The images or other third party material in this article are included in the article's Creative Commons licence, unless indicated otherwise in a credit line to the material. If material is not included in the article's Creative Commons licence and your intended use is not permitted by statutory regulation or exceeds the permitted use, you will need to obtain permission directly from the copyright holder. To view a copy of this licence, visit http://creativecommons.org/licenses/by/4.0/. The Creative Commons Public Domain Dedication waiver (http://creativecommons.org/publicdomain/zero/1.0/) applies to the data made available in this article, unless otherwise stated in a credit line to the data. 
Obstetrics and Gynecology (ACOG) and the Society for Maternal Fetal Medicine (SMFM). The common causes of false positive NIPT results include placental mosaicism [8], foetal chromosome rearrangement, vanishing twin or co-twin demise [11], and familial chromosome abnormalities or malignancy [12].

In contrast, false negative NIPT results involving foetal aneuploidies are rarely found in follow-ups with large numbers of clinical cases [13, 14]. It is generally believed that the main cause of false negatives is the low foetal fraction of cfDNA in the maternal circulation, which is related to higher-weight women, earlier gestational age $(<10$ weeks), and prolonged storage of blood samples prior to processing $(>24 \mathrm{~h})[15,16]$. A few false negative NIPT results were confirmed as placental mosaicism according to a retrospective audit of a large number of chorionic villus samples (CVS) [8-10, 17]. In addition, a low foetal fraction of cfDNA and placental mosaicism have been implicated in some false negative results, while other instances remain unexplained [18]. There is little information on these factors affecting the false negative NIPT results. Notably, false negatives are more likely to cause clinical misdiagnosis, and it is important to study the causes of false negative results in NIPT. Clinical geneticists should be aware of these false negative situations, and patients should be informed of the possibility of discordant results between NIPT and subsequent cytogenetic analyses.
In this study, we reported a case of a foetus that tested "negative" for trisomy 21 by NIPT but was postnatally diagnosed with Down syndrome with a 46,XY,der(21; 21)(q10;q10), 21 karyotype via newborn blood.

\section{Case presentation}

The patient was a one-month-old male who visited Taizhou Hospital with his parents. He was born at $37+4$ weeks gestation by normal vaginal delivery, weighed $2850 \mathrm{~g}$ and had a length of $50 \mathrm{~cm}$. Down syndrome was suspected based on the typical physical features seen at birth, including a flat nasal bridge and up slanting palpebral fissures. Peripheral blood karyotyping confirmed the diagnosis of Down syndrome with the 46,XY,der(21; 21)(q10;q10),+ 21 karyotype in all clones. Complications observed in the neonatal period included neonatal haemolysis, atrioventricular septal defect (AVSD), and patent ductus arteriosus (PDA).

The patient's mother, who was 30 years old with G3P1A1 (height $163 \mathrm{~cm}$, weight $59.0 \mathrm{~kg}$, BMI 22.2), had a 4-year-old healthy child but suffered one spontaneous abortion. During pregnancy, first-trimester ultrasound examination showed a single gestational sac with a heartbeat, and the foetal nuchal translucency (NT) was normal $(1.1 \mathrm{~mm})$ at $12+4$ weeks gestation. Secondtrimester maternal serum screening showed a calculated risk of $1 / 592$ for trisomy 21 at $16+3$ weeks gestation. NIPT results indicated that the foetus was at "low risk"

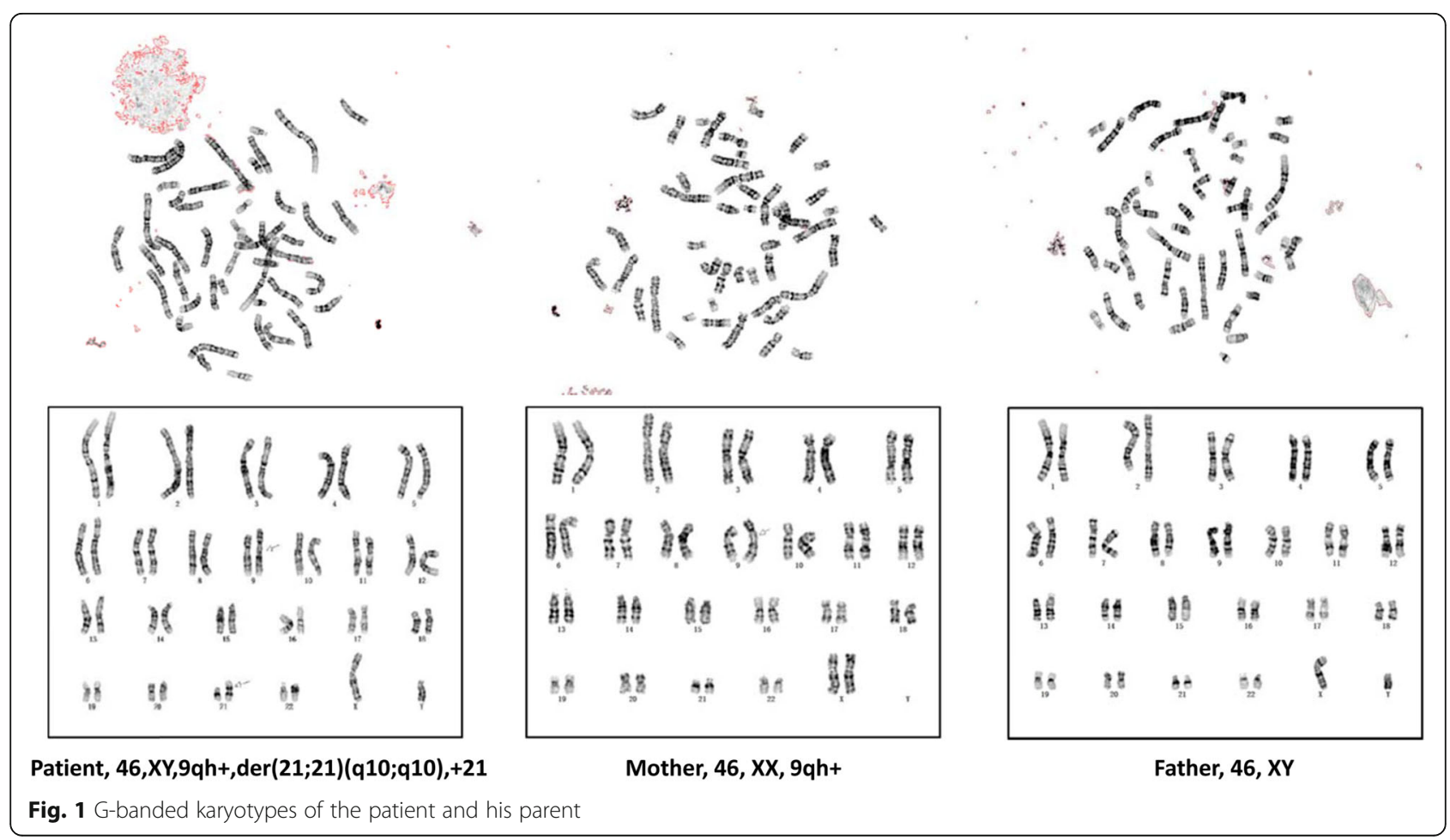




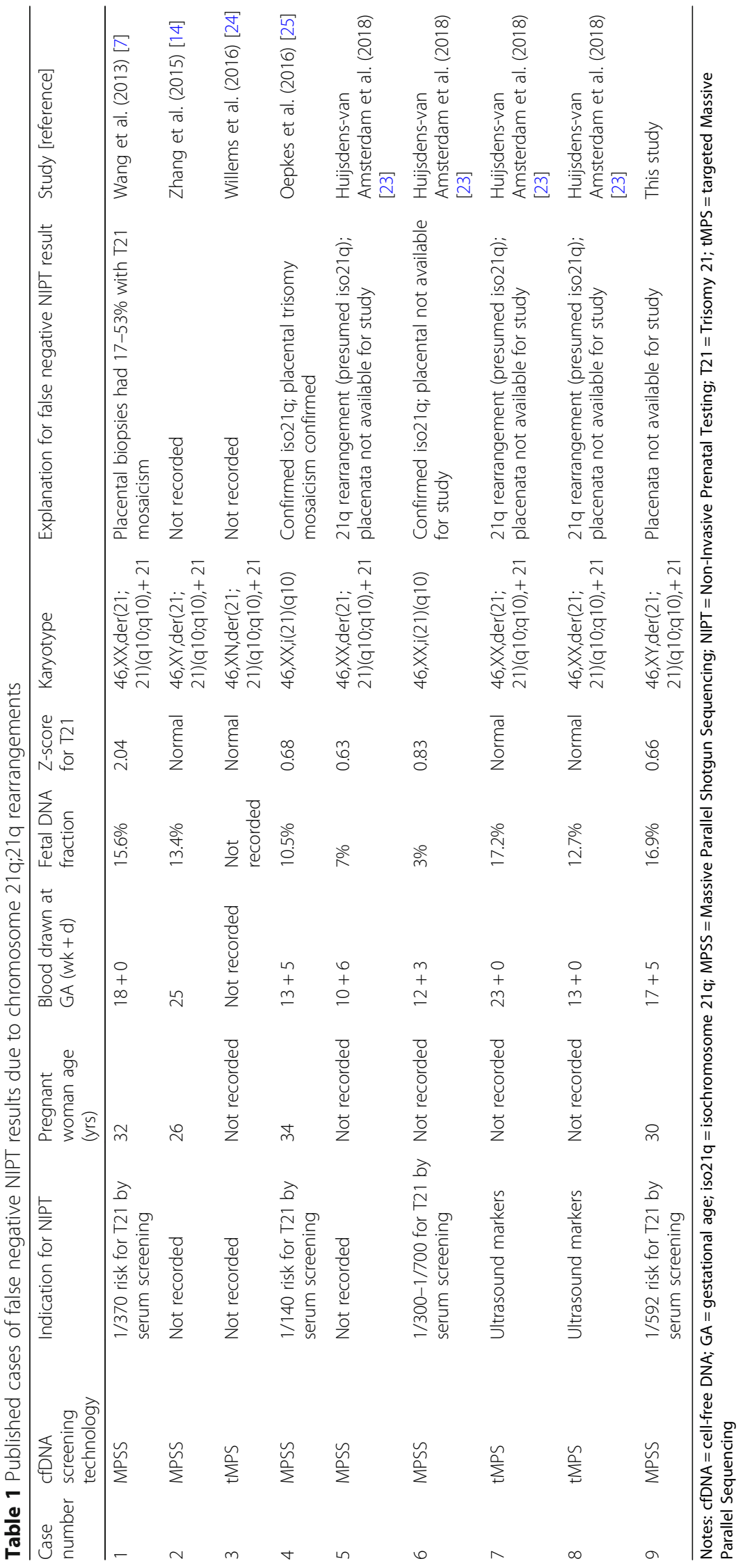


for each of the three common trisomies ( $Z$-score for $\mathrm{T} 21=0.664, \mathrm{~T} 18=0.424$, and $\mathrm{T} 13=0.205)$ at $17+5$ weeks gestation, and the foetal fraction of cfDNA was 16.9\%. The unrelated parents were healthy and had no medical histories. Parental karyotyping showed that the mother was a carrier of the 46,XX karyotype and that the father was a carrier of the 46,XY karyotype (Fig. 1).

\section{Discussion and conclusions}

Trisomy 21, the chromosomal basis of Down syndrome [OMIM \#190685], is the most common foetal aneuploidy and accounts for approximately $3 \%$ of all prenatal karyotyping [19, 20]. Available data on Down syndrome indicate that 94-96\% of cases have standard karyotypes (47, XN , +21), 2-4\% have foetal chromosomal structural rearrangements, and less than $1 \%$ have familial chromosome abnormalities or mosaicism [20, 21]. Robertsonian translocation 14q;21q and chromosome 21q;21q rearrangements are the most common abnormalities in foetal chromosomal rearrangement and occur with equal frequencies. More than 95\% of 21q;21q rearrangements in Down syndrome arise de novo [22]. It is noteworthy that de novo 21q;21q rearrangements are overrepresented $(28 \%, 8 / 29)$ among false negative NIPT results involving Down syndrome; this percentage is an approximately 14-fold increase over the $2 \%$ of live births with Down syndrome [23]. Understanding the biological factors behind this false negative result of de novo 21q; 21q rearrangements can improve prenatal diagnostic follow-up and genetic counselling.

To explore the possible causes of our false negative case using NIPT, we first analysed the known factors that cause a low foetal fraction of cfDNA. The patient's mother underwent NIPT at $17+5$ weeks gestation, with a weight of 59.0 $\mathrm{kg}$ and a BMI of 22.2. Second trimester ultrasound examination did not find the presence of a vanishing twin. Plasma separation of the blood sample was completed within $8 \mathrm{~h}$ of processing. The foetal fraction of cfDNA was $16.9 \%$; this percentage was much larger than the threshold of $4 \%$ for obtaining accurate NIPT results based on the semiconductor sequencing platform (SSP) [24]. Then, we investigated the parental karyotype, which showed that the mother was a carrier of the 46,XX karyotype and that the father was a carrier of the 46,XY karyotype; thus, this case with of 21q;21q rearrangement was a de novo foetal chromosomal 21q rearrangement. However, we could not identify this false negative NIPT case due to potential mosaicism, as we did not collect tissue samples from the umbilical cord and placenta for further examination after delivery. Unfortunately, the patient's mother did not undergo a high-resolution ultrasound examination at 24 weeks gestation.

To our knowledge, this is the 9th report of false negative NIPT results due to chromosome 21q;21q rearrangements. We added this case to the 8 cases that were previously summarized by Huijsdens-van Amsterdam et al. [23] (Table 1). These results showed that false negative NIPT results may occur through biological mechanisms rather than technical limitations or poor quality [7, 14, 23, 25, 26]. 21q;21q rearrangements include isochromosome $21 \mathrm{q}$ rearrangements and Robertsonian translocation 21q;21q. Cytogenetic methods cannot distinguish between a true Robertsonian translocation derived from two different homologous chromosomes and an isochromosome composed of genetically identical arms derived from one parental chromosome. Isochromosome $21 \mathrm{q}$ arises de novo postfertilization due to centromere mis-division or U-type exchange between sister chromatids. Shaffer et al. [27] found that most 21q;21q rearrangements are isochromosome $21 \mathrm{q}(88.9 \%, 32 / 36)$, and the remaining rearrangements are true Robertsonian translocations 21q;21q $(11.1 \%, 4 / 36)$ accomplished by molecular cytogenetic techniques. Down syndrome due to de novo isochromosome $21 \mathrm{q}$ is more likely to result in a false negative NIPT result than that due to standard karyotypes (47, $\mathrm{XN},+21$ ) [23]. A biological cause of the false negative results is almost certainly placental mosaicism arising from the postzygotic formation of 21q;21q rearrangements, which leads to the placental cytotrophoblast having a predominantly normal karyotype [23]. It is important to handle these unexpected false negative NIPT results in prenatal screening.

In conclusion, it is imperative for clinical geneticists and their patients to understand that NIPT is still a screening test. Prior to NIPT, all patients should receive genetic counselling and informed consent on the variety of possible test results, as the risk of false positive or false negative results can occur, to ensure that prenatal patients are able to make more informed decisions regarding the role of NIPT.

\section{Abbreviations}

AVSD: Atrioventricular septal defect; BMI: Body mass index; CVS: Chorionic villus sampling; DNA: Deoxyribonucleic Acid; MPSS: Massively parallel shotgun sequencing; NIPT: Non-invasive prenatal testing; OMIM: Online Mendelian Inheritance in Man; PDA: Patent ductus arteriosus

\section{Acknowledgements}

We appreciate the family for their contribution to this study.

\section{Authors' contributions}

HHX and WWS: concept, acquisition of data, article draft, revised article critically, corresponding author; MZD: performed the peripheral blood karyotyping; KW: provided a genetic counselling to the family and revised article critically; YZ and FYP: carried out NIPT experiments and analyzed obtained results; All authors read and approved the final manuscript.

\section{Funding}

This work was supported by grants from the National Natural Science Foundation of China (81901625). The funding body did not have any role in study design, data collection and analysis, decision to publish, or preparation of the manuscript. 


\section{Availability of data and materials}

All data generated during this study are included in this published article.

\section{Ethics approval and consent to participate}

This study was approved by the Institutional Medical Ethics Review Board of Taizhou Hospital in Zhejiang Province, China (approval \# K20190724). Written informed consent was obtained from his parents.

\section{Consent for publication}

Written informed consent was obtained from the parents of the patient for publication of this case report. The parents consent for the publication of their medical data and images.

\section{Competing interests}

The authors declare that they have no conflict of interests.

\section{Author details}

'Prenatal Diagnosis Center, Taizhou Hospital, Wenzhou Medical University, Zhejiang, China. ${ }^{2}$ Medical Research Center, Taizhou Hospital, Wenzhou Medical University, Zhejiang, China. ${ }^{3}$ Department of Gynecology and Obstetrics, Taizhou Hospital, Wenzhou Medical University, Zhejiang, China.

Received: 26 October 2019 Accepted: 26 June 2020

Published online: 06 July 2020

\section{References}

1. Norton ME, Jacobsson B, Swamy GK, Laurent LC, Ranzini AC, Brar H, et al. Cell-free DNA analysis for noninvasive examination of trisomy. N Engl J Med. 2015:372:1589-97.

2. Norwitz ER, Levy B. Noninvasive prenatal testing: the future is now. Rev Obstet Gynecol. 2013;6:48-62.

3. Zimmermann B, Hill M, Gemelos G, Demko Z, Banjevic M, Baner J, et al. Noninvasive prenatal aneuploidy testing of chromosomes 13, 18, 21, X, and Y, using targeted sequencing of polymorphic loci. Prenat Diagn. 2012;32: 1233-41.

4. Sparks AB, Struble CA, Wang ET, Song K, Oliphant A. Noninvasive prenatal detection and selective analysis of cell-free DNA obtained from maternal blood: evaluation for trisomy 21 and trisomy 18. Am J Obstet Gynecol 2012; 206: 319.e1-9.

5. Mackie FL, Hemming K, Allen S, Morris RK, Kilby MD. The accuracy of cellfree fetal DNA-based non-invasive prenatal testing in singleton pregnancies: a systematic review and bivariate meta-analysis. BJOG. 2017;124:32-46.

6. Faas BH, de Ligt J, Janssen I, Eggink AJ, Wijnberger LD, van Vugt JM, et al. Non-invasive prenatal diagnosis of fetal aneuploidies using massively parallel sequencing-by-ligation and evidence that cell-free fetal DNA in the maternal plasma originates from cytotrophoblastic cells. Expert Opin Biol Ther. 2012;12(Suppl 1):S19-26.

7. Wang Y, Zhu J, Chen Y, Lu S, Chen B, Zhao X, et al. Two cases of placental T21 mosaicism: challenging the detection limits of non-invasive prenatal testing. Prenat Diagn. 2013:33:1207-10.

8. Grati FR, Malvestiti F, Ferreira JC, Bajaj K, Gaetani E, Agrati C, et al. Fetoplacental mosaicism: potential implications for false-positive and falsenegative noninvasive prenatal screening results. Genet Med. 2014;16:620-4.

9. Lebo RV, Novak RW, Wolfe K, Michelson M, Robinson H, Mancuso MS. Discordant circulating fetal DNA and subsequent cytogenetics reveal false negative, placental mosaic, and fetal mosaic cfDNA genotypes. J Transl Med. 2015;13:260

10. Van Opstal D, Srebniak MI, Polak J, de Vries F, Govaerts LC, Joosten M, et al. False negative NIPT results: risk figures for chromosomes 13, 18 and 21 based on chorionic villi results in 5967 cases and literature review. PLoS One. 2016;11:e0146794.

11. Lau TK, Cheung SW, Lo PS, Pursley AN, Chan MK, Jiang F, et al. Non-invasive prenatal testing for fetal chromosomal abnormalities by low-coverage whole-genome sequencing of maternal plasma DNA: review of 1982 consecutive cases in a single center. Ultrasound Obstet Gynecol. 2014;43: 254-64.

12. Cai YH, Yao GY, Chen $L J$, Gan HY, Ye CS, Yang XX. The combining effects of cell-free circulating tumor DNA of breast tumor to the noninvasive prenatal testing results: a simulating investigation. DNA Cell Biol. 2018;37:626-33.

13. Dar P, Curnow KJ, Gross SJ, Hall MP, Stosic M, Demko Z, et al. Clinical experience and follow-up with large scale single-nucleotide polymorphism- based noninvasive prenatal aneuploidy testing. Am J Obstet Gynecol 2014; 211: 527.e1-527.e17.

14. Zhang H, Gao Y, Jiang F, Fu M, Yuan Y, Guo Y, et al. Non-invasive prenatal testing for trisomies 21, 18 and 13: clinical experience from 146,958 pregnancies. Ultrasound Obstet Gynecol. 2015;45:530-8.

15. Hu P, Liang D, Chen Y, Lin Y, Qiao F, Li H, et al. An enrichment method to increase cell-free fetal DNA fraction and significantly reduce false negatives and test failures for non-invasive prenatal screening: a feasibility study. J Transl Med. 2019;17:124

16. Canick JA, Palomaki GE, Kloza EM, Lambert-Messerlian GM, Haddow JE. The impact of maternal plasma DNA fetal fraction on next generation sequencing tests for common fetal aneuploidies. Prenat Diagn. 2013;33: $667-74$.

17. Smith M, Lewis KM, Holmes A, Visootsak J. A case of false negative NIPT for Down syndrome-lessons learned. Case Rep Genet. 2014:2014:823504.

18. Hartwig TS, Ambye L, Sørensen S, Jørgensen FS. Discordant non-invasive prenatal testing (NIPT) - a systematic review. Prenat Diagn. 2017;37:527-39.

19. Jacobs M, Cooper SA, McGowan R, Nelson SM, Pell JP. Pregnancy outcome following prenatal diagnosis of chromosomal anomaly: a record linkage study of 26,261 pregnancies. PLoS One. 2016;11:e0166909.

20. Vičić A, Hafner T, Bekavac Vlatković I, Korać P, Habek D, Stipoljev F. Prenatal diagnosis of Down syndrome: a 13-year retrospective study. Taiwan J Obstet Gynecol. 2017;56:731-5.

21. Zhao W, Chen F, Wu M, Jiang S, Wu B, Luo H, et al. Postnatal identification of trisomy 21: an overview of 7,133 postnatal trisomy 21 cases identified in a diagnostic reference Laboratory in China. PLoS One. 2015:10:e0133151.

22. Wilch ES, Morton CC. Historical and clinical perspectives on chromosomal translocations. Adv Exp Med Biol. 2018:1044:1-14.

23. Huijsdens-van Amsterdam K, Page-Christiaens L, Flowers N, Bonifacio MD, Ellis KMB, Vogel I, et al. Isochromosome 21q is overrepresented among false-negative cell-free DNA prenatal screening results involving Down syndrome. Eur J Hum Genet. 2018;26:1490-6.

24. Liao C, Yin AH, Peng CF, Fu F, Yang JX, Li R, et al. Noninvasive prenatal diagnosis of common aneuploidies by semiconductor sequencing. Proc Natl Acad Sci U S A. 2014;111:7415-20.

25. Willems PJ, Dierickx H, Segers N, Castenmiller C, Verschueren S, DeBoulle K, et al. High positive predictive value (PPV) of cell-free DNA (cfDNA) testing in a clinical study of 10,000 consecutive pregnancies. J Mol Biomark Diagn. 2016;7:285.

26. Oepkes D, Page-Christiaens GC, Bax CJ, Bekker MN, Bilardo CM, Boon EM, et al. Trial by Dutch laboratories for evaluation of non-invasive prenatal testing. Part I-clinical impact Prenat Diagn. 2016;36:1083-90.

27. Shaffer LG, McCaskill C, Haller V, Brown JA, Jackson-Cook CK. Further characterization of 19 cases of Rea(21q21q) and delineation as isochromosomes or Robertsonian translocations in Down syndrome. Am J Med Genet. 1993:47:1218-22.

\section{Publisher's Note}

Springer Nature remains neutral with regard to jurisdictional claims in published maps and institutional affiliations.

Ready to submit your research? Choose BMC and benefit from:

- fast, convenient online submission

- thorough peer review by experienced researchers in your field

- rapid publication on acceptance

- support for research data, including large and complex data types

- gold Open Access which fosters wider collaboration and increased citations

- maximum visibility for your research: over $100 \mathrm{M}$ website views per year

At BMC, research is always in progress.

Learn more biomedcentral.com/submissions 